\title{
С.М. Козлова
}

\section{Сценическая архитектоника «Чайки» А.П.Чехова и смысл}

Прием «театра в театре», использованный Чеховым в «Чайке», неизбежно ведет к семантизации всех элементов архитектуры сцены, так или иначе отмеченных в тексте пьесы и тем самым включенных в ее художественный мир. Образ театра в пьесе, моделирующий реальный мир театра и, далее, мир человеческий как «театр жизни», привлекает исследователей возможностью интерпретировать эстетические идеи Чехова в создании нового театра, нового языка искусства. Продолжая это направление исследований, мы предлагаем описание и интерпретацию некоторых элементов сценической архитектоники пьесы.

Занавес, отделяющий сцену от зрительного зала, обозначает границу между жизнью и искусством. Второй занавес на сцене театра Треплева дублирует это значение, затормаживая слияние жизни и искусства в акте спектакля после подъема первого занавеса. Искусство держит паузу, утверждая себя как тему, проблему, цель представления.

Авторская презентация театра на сцене как «эстрады наскоро сколоченной для домашнего спектакля» создает значение занавеса как границы между искусным (сцена) и неискусным (эстрада), профессиональным и любительским искусством. В четвертом действии дуальность значений сцены и эстрады переоценивается: сиена - топос «грубой жизни», искусства массового, для толпы; эстрада топос интимной, «чистой», «изящной» жизни, искусство для посвященных. Перемена знаков не отменяет ценности того или другого искусства, а утверждает их равноценность; сиена и эстрада продолжают сосуществовать: «...цел ли наш театр. А он до сих пор стоит» [Чехов, 1978, с. 57; в дальнейшем тексты А.П. Чехова цитируются по этому изданию с указанием в круглых скобках тома римскими цифрами и страниц арабскими цифрами].

Ремарка Чехова в зачине пьесы дает еще одно значение занавеса: «Широкая аллея ... загорожена эстрадой ..., так что озера совсем не видно» (XIII, 5) - занавес разделяет мир человеческий и мир природы. Причем мир человеческий отождествляет и персонажей и зрителей. Это тождество обусловлено функцией персонажей - тоже зрителей треплевского театра - и театральной перспективой точки зрения зрителя, которая сливается с точкой зрения зрителя-персонажа, что оговорено также в чеховской ремарке: «Широкая аллея, ведущая по направлению от зрителя в глубину парка к озеру», - то есть перспектива художественного мира «в глубину парка» - включает местоположение реального зрителя в зале ${ }^{1}$. Занавес, скрывающий сцену и природу от человека в развития линии зрительской перспективы, приобретает значение тайны искусства, тайны законов жизни и природы. Театр Треплева - это попытка заглянуть за занавес, постичь одну из тайн мира хотя бы в мечтах. Там, за занавесом открывается «жизнь не такая, как она есть и

1 Эту особенность отмечает Ежи Фарыно: «Благодаря тому, что Треплев использует «естественные» декорации, «внеэстрадный» мир пьесы получает смысл подлинной (не театральной) действительности и способствует устранению (либо смягчению) границы «сцена (мир «Чайки») - зрительный зал» [Фарыно, 1994, с. 99]. 
не такая, как должна быть, а такая, как она представляется в мечтах».

В этом смысле занавес - это еще и завеса времени. Поднимается занавес - и открывается даль будущего: «через двести тысяч лет». Еще раз в этом акте занавес поднимется, чтобы открыть бесконечную даль прошлого. Абсолютное - мифологическое - прошлое обозначено библейской аллюзией соблазнения Евы Дьяволом, возникающей в пересказе Дорном последней сцены треплевского спектакля: «Когда эта девочка говорила об одиночестве и потом, когда показались красные глаза дьявола, у меня от волнения дрожали руки» (XIII, 18). Невольная замена мировой души «девочкой» предваряет повторение в настоящем вечной коллизии соблазнения невинной души дьяволом: происходит первое знакомство Нины - чистой девы - с Тригориным, в характере которого Аркадина отмечает свойство явно дьявольское: «Когда ему говорят хорошие слова, то он проваливается», - или еще раньше Нина: «Играть при нем мне страшно и стыдно». В момент «конфуза» вечной Евы и вечного Дьявола Дорн предлагает «поднять занавес», открывая еще одну тайну мира - его неизменность, вечную повторяемость в разных комбинациях «атомов» одних и тех же коллизий ${ }^{1}$.

Дальнейшая дифференциация мира посредством занавеса создает новые семантические оппозиции: естественная жизнь природы за занавесом противостоит искусственной театрализованной, масочной жизни перед занавесом (Треплев и Аркадина экспромтом играют диалог из «Гамлета»); занавес - это граница между внешним и внутренним миром человека («Мой сын! Ты очи обратил мне внутрь души»), между явью и сном («усыпите нас, и пусть нам приснится ..., пусть мы спим»), между преходящим и вечным, бытием и небытием («Через двести тысяч лет ничего не будет... Так вот пусть изобразят нам это ничего»).

При этом занавес не несет, как мы уже говорили, отчетливой аксиологической функции дифференциации ценного и неценного. Так, мир зазанавесом включает значения природного, духовного, неискусного, так же, как и мир перед занавесом представляет искусное и профанное, искусственное и реальное. Будучи включенными в более общее семантическое поле, оппозиции не разрешаются, а снимаются ликвидацией занавеса в прямом и переносном значении слова: «Никто не имеет основания отделять дух от материи» (идеальное и материальное); «Каждый пишет так, как хочет и как может» (искусное и неискусное, реализм символизм); «Теперь можно поднять занавес, а то жутко» (человеческое и природное); «Театр так и замер. Пауза. Тихий ангел пролетел» (преходящее и вечное). В то же время пластичность, подвижность, «диалектичность» занавеса как метонимии театра и, шире, искусства определяет его необходимость. Он регулирует отношения между противоположностями, формирует и поддерживает тенденции их синтеза в общей гармонии мира. Ликвидация занавеса ведет, с одной стороны, к тотальной театрализации жизни, с другой стороны, - к тотальной натурализации искусства. Так, во втором действии занавеса нет, и пространство просцениума сливается с пространством эстрады, образуя общее игровое поле; семантика которого как ненастоящей жизни обозначена «площадкой для игры в крокет». В треть-

${ }^{1}$ М.С. Григорьев в свое время (1924 г.) писал, что против идеи прогрессивного совершенствования в той форме, как она развивалась в пьесах Чехова, могут быть возражения, Чеховым предусматриваемые (идея Вечного Возращения Ницше, или механическое представление о времени, как сложенном из отдельных кусков, в которых отдельные отрезки могут повторяться) [Григорьев, 1924, с. 39]. Сам Григорьев решительно отверг эти «возражения», настаивая на положении о прогрессивном развитии Чехова. Анализ показывает, что Чехов тяготеет к идее эволюции, предполагающей преемственность, традицию, повторяемость исходных элементов культуры (см. об этом нашу статью [Козлова, 2001, c. 51-57]. Есть так же мнение Г.А. Шалюгина, считающего, что источником идеи возвращения у Чехова является Экклезиаст (XIII, 6) [Шалюгин, 1993, с.11]. 
ем акте отсутствие второго занавеса как необходимого элемента сценической архитектоники обнаруживает неподлинность искусства натуральной жизни, лишенного идеальных форм Природы и Бытия и только удваивающего житейские дрязги. В четвертом действии эстрада и занавес вынесены за сцену, что может означать девальвацию искусства: «Театр голый ... и занавеска от ветра хлопает». Между «театром» и «кабинетом» воздвигнута стена, только стеклянная дверь обещает взаимодействие между ними. Стена сужает пространство действия, уплощает его и означает новую стадию дробления мира, обособление «делового», коммерческого искусства, отчужденного от театра и от жизни, от быта и от Бытия. Театр (голый) и занавес (занавеска) утрачивают теургическую, миростроительную функцию, в мир входит случай (игра в лото), хаос (бушующее озеро, «хаос грез и образов») и смерть.

Декорация. Столь же важную роль в архитектонике «Чайки» выполняет задник театральной сцены. Как и занавес, он является многофункциональным элементом в пьесе. Во-первых, это намалеванное полотно, скрывающее часть сцены, которая преобразуется в тексте пьесы в пространство «за сценой», заполненное невидимыми зрителю элементами художественного мира. Во-вторых, для зрителей, сидящих в зале, - это видимая часть художественного мира: «парк в имении Сорина», аллея, кусты, озеро, луна. В-третьих, для зрителей - персонажей - это условная декорация эстрадной сцены Треплева, ее задняя стена, в то время как для зрителей зала и Треплева - это знак отсутствия декорации: «Вот тебе и театр. $<\ldots>$. Декораций никаких» (XIII, 7). В-четвертых, элементы сценического пространства и художественного мира чеховской пьесы, не являясь декорацией спектакля Треплева, включены тем не менее в его художественный мир и получают в нем противоположные значения. В авторском мире озеро, луна - это знаки бытия, причем естественного, подлинного бытия, в то время как в мире спектакля Треплева - это знаки небытия - «пустого пространства»: «Вот тебе и театр. Занавес, потом первая кулиса. Потом вторая и дальше пустое пространство» (XIII, 7).

Тогда в целом вся сцена первого акта представляет собой мировой Универсум: просцениум - сфера Быта, сцена - сфера Бытия, эстрада - сфера Ума и «пустое пространство» Небытия. Внутри этого Универсума «наскоро сколоченная эстрада» - метафора жизни человека вообще, а в контексте мира пьесы - пророческий образ судьбы героя, «не нашедшего свою дорогу»: два года между третьим и четвертым действиями, два действия между первым актом - началом жизни Треплева - и последним - ее концом - это и есть «первая кулиса, потом вторая и дальше пустое пространство». Перед первой кулисой - любовь, за ней - ненависть, перед второй - слава писателя, за ней - «хаос грез и образов», дальше - «ничего», «никаких декораций».

Отсутствие декорации на эстраде создает иллюзию проницаемости задней стены сценического пространства и его бесконечности в прямой перспективе, образуемой точкой зрения сидящих в зале. Прямая перспектива пронизывает весь Универсум, последовательно преобразуя плоскости театральных рам вплоть до декоративного задника в свободное пространство. В этой перспективе жизнь не начинается и не кончается на сцене, а продолжается, перетекая из зала через рампу, сквозь первую раму театральных подмостков, затем, отдаляясь и уменьшаясь, сквозь раму театра Треплева, затем двухлетнее ее скрытое течение вливается сквозь совсем отдаленный в засценическое пространство голый остов заброшенного театра, чтобы наконец там, где скрещиваются параллели, погасла звезда Треплева и зажглось новое восходящее светило актрисы Нины Заречной, одинокой мировой души, вобравшей в себя все души живых, встретившихся ей на пути.

Таким образом, принцип фрагментарности пьесы Чехова, который моделирует спектакль Треплева, не имеющий ни названия, ни продолжения, ни конца, имеет силу только в плоскости одной или другой рамы, лимита текста пьесы или того 
или другого эпизода, но не в перспективном плане, отражающем диалектику развития жизни, судьбы, ее продолжения и конца, который есть начало новой жизни и судьбы.

Проницаемость задней стены создает возможность обратной перспективы, образуемой точкой зрения предполагаемого автора.

Отношение прямой и обратной перспектив формирует ценностноиерархический ряд форм искусства с противоположными знаками. В плане прямой перспективы, то есть с точки зрения публики, самой крупной фигурой мира искусства является Аркадина - знаменитая актриса, играющая в пьесах массового спроса; затем Тригорин - «известный писатель», который пишет «чудесные рассказы»; затем - уменьшающаяся в зрительской перспективе фигура Треплева неизвестного «декадента»; наиболее удаленная и малая величина Нины - начинающей актрисы домашнего любительского масштаба - и совсем уже не видимая, мифическая фигура Автора с его «новой» пьесой.

Содержание этой иерархии выражено мнением Нины. Для нее публика «обыкновенные люди», «толпа», которая «выше всего ставит знатность происхождения и богатства» - область низкой рабской материи. Над ней возвышается «богема» - мир свободной творческой стихии. Ее венчает Олимп - «известные люди», которые «горды, неприступны ... Они презирают толпу».

Обратная перспектива снижает, обытовляет олимпийцев: Тригорин «удит рыбу», Аркадина - плакса, «скряга» и оказывается ближе всех к презренной толпе, уважающей знатность и богатство. Но, главное, обратная перспектива поддержана пространственным положением представителей различных форм искусства и создает противоположный иерархический ряд. Иерархию обратной перспективы отражает ступенчатая архитектура мизансцены, которая вписана в архитектуру театpa. Нижний ярус иерархии занимает публика первых кресел - богатые купцы, кумиром которых является Аркадина, располагающаяся на следующей ступени вблизи от своей публики. Рядом с ней более крупная фигура более модного беллетриста Тригорина. Над ними - на эстраде Треплев - творец новых форм в искусстве («... я талантливее вас всех ... Вы, рутинеры ...» (XIII, 40)). Самую высокую позицию в этом плане занимает Нина Заречная, тематически освященная как истинная «жрица святого искусства»: «вся в белом», «на большом камне». И выше нее - «фигура» Автора, который «талантливее всех». Его амбициозная позиция уравновешивается его положением в прямой перспективе, смысл которого выражен мнением толпы: «Хороший был писатель, но он писал хуже Тургенева» (XIII, 30).

При этом иерархия форм искусства в обратной перспективе, направленной к зрителю, не отменяет ни одной из этих форм: «Всем хватит места, и новым и старым - зачем толкаться?» (XIII, 34) - в отличие от точки зрения публики, в плане которой очевидна тенденция к умалению и ликвидации «непонятных», «новых», не востребованных толпой форм искусства: отношение Аркадиной к спектаклю сына, прервавшее его развитие.

Чеховская иерархия искусства не является застывшей. Именно благодаря прозрачности, проницаемости декоративного фона и обусловленной им системе перспектив, внутри иерархии создается напряженная драматическая динамика встречных потоков сюжетного движения главных героев, их скрытого и видимого развития. Так, Треплев в видимой прямой перспективе переживает эволюцию: «вышел в настоящие писатели», «и деньги стали из журналов присылать ... И красивый стал», и «почитатели шлют поклон». Тогда как скрыто он регрессирует к «рутине», к отверженности, к смерти. В то же время Нина, напротив, в видимой и прямой перспективе регрессирует: «личная жизнь не удалась совершенно», а «сцена ... еще хуже» (XIII, 50), а в обратной перспективе эволюционирует от простушки, дилетантки к «настоящей актрисе», от мнений, которые она разделяла с 
толпой, к глубоко выстраданной мудрости - «главное не слава, не блеск ..., а умение терпеть. Умей нести свой крест и веруй» (XIII, 58), от начала жизни к ее продолжению и совершенствованию: «когда я стану большой актрисой ...» (XIII, 59).

Приемом импликации развития характера Нины является сложная система взаимодействия сценического и засценического пространства (см. ниже). Инволюция Треплева и Тригорина отмечена в смене декораций. Гений Треплева, его новая форма искусства в декорации первого действия органично вписаны в природное - не бытовое, а бытийное пространство сцены. Декорация второго действия, на фоне которой протекает исповедание таланта Тригорина также представляет природное пространство: «Налево видно озеро, в котором, отражаясь сверкает солнце. Цветники» (XIII, 21). Но оно уже стеснено бытом: «Направо дом с большой террасой», а полуденное солнце, отраженное в озере, скрывает Вечность, сквозившую через «декорации» Треплева. Декорация третьего действия представляет бытовое пространство, функционально противоположное духовному - творческому: «столовая в доме Сорина». Даже время обозначено материальнобытовым образом: «Тригорин завтракает».

Пространство четвертого акта тоже камерное, бытовое: «Одна из гостиных в доме Сорина» (XIII, 45). Значима его функциональная перекодировка: гостиная, «обращенная Константином Треплевым в рабочий кабинет». Эта перемена функций прежде всего является знаком разрыва человеческих коммуникаций: гостиная уже не служит местом для гостей. Это значение подкрепляется отсутствием на сцене в момент начала действия персонажей, а когда они появляются (Медведенко и Маша) началом их речевого действия становится окликание хозяина, констатация пустоты («Нет никого») и объявление темы одиночества, главной в этом акте: Медведенко (о Сорине): «Боится одиночества». С другой стороны, перефункционирование места и образа жизни Треплева означает его профессионализацию, его «служение ... святому искусству», и он «попал в круговорот» «дней и ночей», в котором суетится Тригорин, о чем позднее скажет Нина: «Вы писатель, я актриса ...Попали и мы с вами в круговорот ...» (XIII, 57). Стена кабинета отчуждает Треплева от жизни, природы, от недовоплощенных им новых форм театра. Дух как будто действительно отделился от материи жизни, которая осталась за занавеской его театра, где плачет, тоскует ее мировая душа.

Важное значение в декоративном оформлении сцены имеет «стеклянная дверь», она - в центре сценической перспективы. Ее стеклянность означает хрупкость, тонкость, ненадежность перегородки, отделяющей комфортный мир цивилизации от мира природных и социальных стихий, уединенный книжный мир Треплева от жизненных бурь. Звуки, голоса внешнего мира проникают сквозь тонкую перегородку, томят и беспокоят его душу. Стеклянная дверь - это дверь в сад, к театру, к озеру. И через нее входит и выходит навсегда только Нина.

Кулисы разделяют подмостки на сиеническое и закулисное пространства. Чехов активно включает закулисную часть сцены в художественный мир пьесы, расширяя пространство сценической жизни героев. При этом закулисное пространство реализует и коннотативные значения скрытого от зрителя мира театра как театра жизни: непубличная, приватная или потаенная жизнь людей.

За кулисами располагается мир, сосуществующий одновременно с миром на сцене, который является только обозримой частью целого. Входы и выходы персонажей мотивируются составом этого целого. Так, в начале первого акта Маша и Медведенко «идут слева, возвращаясь с прогулки», а Сорин и Треплев «входят справа». Левая и правая позиции, обозначающие выходы за кулисы, семиотичны. Слева - озеро, сад (второй акт), выход из дома (третий акт), дверь в столовую (четвертый акт). Справа в той же последовательности актов - дом, ход внутрь дома, дверь, куда уходит стреляться Треплев. Левое, таким образом, несет положительную семантику природы, свободы, жизни в отличие от правого, обозначающе- 
го быт, замкнутость, смерть.

В первом действии на сцене сад, прямо на дальнем плане - озеро, дом - за кулисами. Во втором действии дом выдвигается справа на сцену и теснит озеро влево, а в следующем третьем действии заполняет всю сцену, раскрываясь зрителю своим внутренним пространством, наиболее удаленным от сада и озера, которые оказываются за сценой. Наконец, в четвертом действии дом открывается другой своей половиной, выходящей в сад и на озеро. Таким образом, весь мир на сцене и за сценой совершает медленный круговорот справа налево по ходу солнца, если смотреть из зрительного зала, и слева направо - по ходу Земли с ракурса сцены. Время оборота ровно сутки сценического времени: от заката в начале первого действия до заката в четвертом действии, между ними во втором и третьем действии «полдень» ${ }^{1}$.

В зону пространства за сценой входят «усадьба покойной матери» Нины «на том берегу озера» - и «шесть помещичьих усадеб тут на берегу» (XIII, 16), так что имение Сорина на сцене оказывается частью провинциальной помещичьей России, разоряющейся (Сорин - значение его фамилии соответствует состоянию его хозяйства), утрачивающей родовые фамилии и положение (Аркадина - сестра Сорина - актриса, жена киевского мещанина), оставляющей родовые гнезда без будущего, отторгая от них детей (судьба Нины и Треплева). И только в памяти Аркадиной оживает «шумная», «радостная», наполненная любовью и музыкой усадебная жизнь всего лишь 10-15-ти-летней давности. Промелькнувшие между третьим и четвертым действием два года создают ощущение все более ускоряющегося бега времени.

В первом действии в центре сценического пространства - эстрада, топос искусства, искусственного мира, «загораживающего» естественную жизнь природы и людей, которая погасла, умерла на сцене треплевского театра. Тема спектакля на эстраде проецируется на просцениум, противопоставляя, таким образом, условному, застывшему миру на сцене теплый динамичный мир закулисной жизни. За сценой - дорога, по которой мчится под красным небом Нина из дома отца и мачехи к Треплеву, а затем Треплев уезжает по той же дороге к ней.

Главной героиней засценического пространства является Нина Заречная. Это находит отражение в ее гидронимической фамилии: она из-за озера, с того берега, где усадьба ее покойной матери. Образ ее овеян сказочной, романтической поэзией: она пленена отцом и злой мачехой, но и сама пленяет всех своей красотой и юностью: «Треплев. ... Волшебница, мечта моя!» (XIII, 9). Большую часть своего сценического действия она находится на эстраде и потом за занавесом, не принимая участия в скандале. И таким образом, заключает в своем характере все качества мира за занавесом (см. выше). Ее идеальность, неискушенность, наивная прямота окажутся необходимы в следующем действии для остраннения других характеров.

Движение Треплева в пространстве сиена - кулисы намечает отчетливое противостояние его всем другим персонажам. Все сидят на сцене перед эстрадой, Треплев - за сценой. Все удаляются за кулисы - идут в дом, Треплев появляется на сцене. Посредническую роль между ним и другими пытаются играть Дорн и Маша, но он отвергает их попытки: «Оставьте меня!»

Во втором действии на сцене в центре «площадка для крокета». «Площадка

\footnotetext{
${ }^{1}$ Время «полдня» определяется на основании текста второго действия, где в авторской ремарке указывается «полдень», и в репликах Маши и Дорна речь идет о завтраке: «Маша (встает). Завтракать пора, должно быть»; «Дорн. Пойдет и перед завтраком две рюмочки пропустит» (XIII, 24). В ремарке к третьему действию время не указывается, но косвенно оговаривается «Тригорин завтракает» (XIII, 33), следовательно, действие происходит в полдень.
} 
для крокета» не функционирует в своем прямом значении (никто в крокет не играет) и, следовательно, носит знаковый характер. Игровая семантика этого образа связывает второй акт с первым - «театральным». За кулисами - дом и озеро. Сценическое и закулисное пространства образуют семантические оппозиции театрального - естественного, публичного - приватного, в поле которых раскрываются характеры главных героев.

Первой на «площадку» вступает Аркадина - актриса; ее поведение театральное, она показывает себя, демонстрирует свою внешнюю форму и «правила» жизни, которые так же театральны: она «не заглядывает в будущее, никогда не думает ни о старости, ни о смерти» (XIII, 21). Потом в разговоре с сыном выясняется, что и прошлого она не помнит. То есть Аркадина живет одним настоящим, олицетворяя хронотопический принцип сцены, где все происходит только здесь и сейчас. Так же и другие проповедуемые ею «правила» содержат ту же театральную - костюмную, демонстрационную семантику: « ... держу себя в струне ... всегда одета и причесана comme il faut ... хоть пятнадцатилетнюю девочку играть» (XIII, 21-22). Последний, буквально театральный, образ неожиданно оборачивается в следующем эпизоде своим не игровым аспектом, разоблачая до детскости неразвитое и пустое душевное содержание знаменитой актрисы: слезы, капризы, беспомощность перед управляющим. Неформальное поведение Аркадиной совершенно разрушает образ, который она только что создала, в нем нет и следа корректности, сдержанности, способности «не быть фефелой, не распускать себя». Развитие характера Аркадиной без маски переносится «за сцену», с «площадки для игры» - в «дом» и разрабатывается в комической тональности. Остранненносерьезная позиция Нины («Как странно видеть, что известная артистка плачет, да еще по такому пустому поводу!» (XIII, 26)) имеет двойственное значение. С одной стороны, выражает наивное, неконвенциональное отношение Нины к искусству, а с другой, - стратегию автора на цеелое в характере человека.

Функция крокетной площадки как места репрезентации внешних ролевых форм жизни объясняет в тех же значениях выступление на ней Треплева и Тригорина.

Треплев - не актер, его игра - способ жизни. Она не рассчитана на публику, напротив, он стесняется публичности и заботится лишь об одном зрителе, от которого зависит его жизнь. Прежде чем разыграть свой «спектакль», он беспокоится о том, чтобы не было посторонних глаз:

«Треплев (входит без шляпы, с ружьем и с убитой чайкой). Вы одни здесь?

Нина. Одна.

Треплев кладет у ее ног чайку» (XIII, 27).

Игра, избранная им, - мистификация: и «неузнаваемый» облик его («без шляпы»), и «убитая чайка», и театральный жест - «кладет у ее ног», и предсказание «скоро я убью ... самого себя» - все загадка, тайна. Цель этой мистификации ввести в игру Нину, заставить ее разгадывать «символы» и тем самым вызвать ее на решительное объяснение. Но Нина разрушает это намерение: «Я слишком проста, чтобы понимать вас» (XIII, 27). И Треплев, как и Аркадина, не выдерживает роли и разоблачается, до конца обнажая «гвоздь» проблемы: «О, что тут понимать?! ... У меня в мозгу точно гвоздь, будь он проклят вместе с моим самолюбием, которое сосет мою кровь, сосет, как змея ...» (XIII, 27). Комическая сторона героя без маски обозначена и здесь уже прямой авторской ремаркой, описывающей жест капризного, самолюбивого ребенка: «Топнув ногой», а потом «Дразнит».

Гипертрофированное самолюбие как внутренний стержень его характера имеет свое оправдание в одиночестве, бедности, неудачах героя. Уязвляя его гордость, они заставляют защищать ее от презрения окружающих, подозреваемого им в родных и любимых людях, и от того еще более болезненного. И необыкновенный «театр», и «мировая душа», и «убитая чайка», и первая попытка самоубийства 
- это все театральные маски, символические костюмы уязвленного самолюбия Треплева. Понятна психологическая подоплека загадки убитой чайки. Говоря о своей «подлости» убийства чайки, Треплев подразумевает подлость измены Нины, возлагая на нее вину за его «скорое» самоубийство, то есть театрально вуалирует намерение слабохарактерного и самолюбивого человека вернуть внимание к себе страхом ответственности другого за его жизнь.

Эта его суть определяет и творческую недостаточность Треплева. Его вдохновение зависит от капризов самолюбия. Приезд матери, любовь Нины вдохновляют его. Для них, из желания быть их достойным он творит свой «театр» как высшую художественную ценность. Но малейшее невнимание к нему немедленно уничтожает в его глазах всю ценность творения, лишает его творческого импульса: «Я все сжег, все до последнего клочка» (XIII, 27); « ... она меня не любит, я уже не могу писать» (XIII, 40).

Стихийность, некоммуникабельность его творческой психологии и жизни обозначена его засиеническим поведением: «Целые дни проводит на озере».

Тригорин так же «целый день ловит рыбу», но его засценическое пространство - не дикие окрестности озера, а «купальня». Отмеченность этого образа создает проблематичность рыбацкой страсти Тригорина и ориентирует на ее метафорическое восприятие.

Раздробленность характера Тригорина, раздвоенность его поведения на частное и публичное демонстрируется двойным проходом его по сцене. Первый раз он идет за Аркадиной в глубине сцены, слева, где «предполагается купальня», в дом, с атрибутами рыбака: удочка и ведро. Второй раз он появляется на игровой площадке справа с книжкой в другой роли. Театральность его торжественного выхода на публику иронически разоблачается Треплевым: «Вот идет истинный талант; ступает, как Гамлет, и тоже с книжкой». (Дразнит). «Слова, слова, слова ...» (XIII, 28). Книжная атрибуция Тригорина отмечена трижды: в авторской ремарке «идет с книжкой», в приведенной реплике Треплева и еще раз в ремарке «записывает в книжку» (XIII, 28), и этим определяется первостепенная важность функциональной, ролевой стороны его характера. Аркадина в своей публичной роли только лжет, Треплев живет, а Тригорин функционирует. Аркадина кроме того, что она актриса, может быть еще женщиной, матерью, капризной девочкой, любовницей. Треплев то может писать, то не может писать. Тригорин не может не писать, ничем и никем другим, кроме как писателем, он быть не может. Значимо сравнение его себя с пчелой («для меда ... я собираю пыль с лучших своих цветов»(XIII, 29)), Подобно пчеле, он перерабатывает собственный организм в «слова, слова, слова». Мания Тригорина, поражающая как графомана, так и истинный талант, была бы невинной, если бы питалась только его собственной жизнью («съедаю свою жизнь»). Но для него и другие жизни не цель, а средство, материал. И чем больше истощается его душа («...я уже забыл и не могу себе представить, как чувствуют себя в 18 - 19 лет»), тем больше дьявольская потребность в чужих душах («...рву самые цветы и топчу их корни»). Тригорин - ловец душ - вот метафорическая изнанка его рыбацкой страсти. При первом знакомстве с Ниной он после этикетного комплимента и короткой «паузы» вожделенно заговорил ... о «рыбе»: «Должно быть в этом озере много рыбы ... Для меня нет больше наслаждения ...» (XIII, 16-17). «Улов», который он демонстрирует, выходя на сцену, запись в книжке о Маше (XIII, 28). И в своей исповеди он «проговорился»: «Ловлю себя и вас на каждой фразе ...». Последней его жертвой будет Треплев, за душой которого он явится в четвертом акте: «Завтра отправлюсь на озеро удить рыбу. Кстати, надо осмотреть сад и то место, где - помните? Играли вашу пьесу. У меня созрел мотив ...» (XIII, 52). Эта фраза, где в одном ряду удить pblбу, осмотреть сад, вашу пьесу и созрел мотив, не оставляет сомнений в иносказательном смысле образа Тригорина - рыбака. 
Действительной же страстью и сутью Тригорина является не рыбная ловля, а nраздность: сидеть на берегу, «смотреть бы на поплавок» - идеал труженика разночинца, не знавшего счастливого детства, беспечной сытой юности, своего дома («Если бы я жил в такой усадьбе, то разве я стал бы писать?») ${ }^{1}$. Но тяжелый труд и такого рода праздность не имеют цены в публике (сравните с Треплевым, который «стыдится и боится своей праздности» - (XIII, 36)). Толпа «видит в художнике счастливца» и ценит в нем только «вдохновение». Для публики Тригорин и играет роль модного беллетриста, «спешит, суетится».

Как ни искренен монолог Тригорина, как ни соблазняет близость некоторых его мыслей автору придать ему серьезность, статус творческого сredo Чехова или его исповеди ${ }^{2}$, следует помнить, что исполняется он на «площадке для игры в крокет». Театральная суть монолога раскрывается в следующих моментах. Вопервых, риторический зачин представляется самоцитацией, что подтверждает фразеологический повтор «день и ночь думает, например, все о луне ... День и ночь одолевает меня», - воспроизводящий название книги Тригорина «Дни и ночи». Это все позволяет предположить, что перед нами не спонтанная речь, а «читка». Во-вторых, ключом к психологическому подтексту там, где риторика уступает место живому чувству, может служить подозрение Тригорина, что «внимание знакомых, похвалы, восхищение, - все это обман, меня обманывают, как больного» (XIII, 29). Желание не обмануться в восхищении Нины, вызвать ее искреннее сочувствие и внимание подвигают Тригорина на откровенность. Нина долго «не понимает» его, так как она-то не играет, не обманывает. Наконец, он достигает своей цели, - Нина сочувствует ему: «Вы заработались ... Пусть вы недовольны собой...», - впадает в патетику: «Я отдала бы толпе всю свою жизнь, но сознавала бы, что счастье ее только в том, чтобы возвышаться до меня, и она возила бы меня на колеснице». Тригорин как будто сдерживает и снижает ее пафос: «Ну, на колеснице ... Агамемнон я, что ли? - Она улыбнулась» (XIII, 31). Но при этом он лишь перевел восторг Нины на себя и намекнул невольно, что он не Агамемнон, а Аполлон - Феб. Эта оговорка Тригорина кореллируется фразой Треплева, который так и представил Тригорина Нине: «Это солнце еще не подошло к вам, а вы уже улыбаетесь» (XIII, 28). После этих слов начинается разговор Тригорина с Ниной, и заканчивается намеком на Феба-солнце.

Раздвоенность, «метание» Тригорина между сутью и ролью, между «благодатью» озера и мученическим трудом в доме, между Ниной и Аркадиной отражены в ремарках последней сцены второго действия:

«Голос Аркадиной (из дому). «Борис Алексеевич!».

Тригорин. Меня зовут. Должно быть укладываться. А не хочется уезжать. (Оглядывается на озеро). Ишь ведь какая благодать! ...

${ }^{1}$ Праздность - черта автобиографическая: «Я думаю, что близость к природе и праздность составляют необходимые элементы счастья» (А.С. Суворину, 9 мая 1984; (V, 296). Ирония, или вернее, самоирония отчуждения этой черты в образе Тригорина в том, что функция писательства лишает его глубокого человеческого стремления к «празднику», радости жизни, оставляет его в разряде низших существ. (В письме к Суворину: «...праздность - не лень»).

${ }^{2}$ Наиболее точную форму отношения в «Чайке» автобиографического, тематического и игрового элементов впервые дал С.Д. Балухатый: «Значение введенных Чеховым в пьесу автобиографических элементов в том, что, группируя их вокруг центральной повествовательной темы (о задачах и значении нового театра, о литературной манере), Чехов вновь обсуждал проблему новой драмы, демонстративно выдвигая в речах персонажей волнующие его темы и подкрепляя их одновременно конкретными приемами сложения самой драмы. «Чайка» по подбору тематического материала есть публичное, драматургически стилизованное исповедание автора, художественная игра материалом интимным, "наболевшим" ...» [Балухатый, 1927, с.105]. 
В окне показывается Аркадина.

Аркадина. Борис Алексеевич, где вы?

Тригорин. Сейчас! (Идет и оглядывается на Нину; у окна Аркадиной). Что?

Аркадина. Мы остаемся.

Тригорин уходит в дом» (XIII, 32).

Эта картина, кроме того, показывает, что «площадка для игры в крокет» может быть еще иносказанием о цели игры. Цель игры в крокет - загнать, проведя через препятствия, деревянный шар в лузу. Собственно этой цели добивается своей игрой и в этом и в последующих действиях Аркадина, «загоняя» Тригорина в «дом», в «плен». Ту же цель по отношению к Нине преследуют Тригорин и Треплев.

Неподлинность театрализованных форм жизни разоблачается наивнопростодушной точкой зрения Нины, которая «не понимает» ни Аркадину, ни Тригорина, ни Треплева. Они представляются ей «странными» и, наконец, всю эту разыгранную жизнь она называет «сном», объединив тем самым театр Треплева и сцену жизни, так что слова сына и матери по поводу спектакля на эстраде вдруг приобретают буквальный смысл: «Треплев. $<\ldots>$ усыпите нас, и пусть нам приснится <...> Аркадина. Пусть. Мы спим» (XIII, 32).

В третьем действии происходит полный обмен содержания сценического и закулисного пространства. Вся закулисная - домашняя, скрытая от публики жизнь теперь развертывается на сцене. Причем приватизация пространства становится тотальной, так как захватывает и его закулисную часть. Уходы персонажей со сцены предполагают ближний домашний план: кабинет, гостиная.. Большой мир природы или социума никак не просматривается в «окна» и «двери» декораций.

Здесь жизнь - не сон, выстрел Треплева разбудил царство теней, и она предстала такой, «какая она есть» - со скандалами, истериками, объяснениями, признаниями, борьбой интересов - жизнь грубая, некрасивая, не оформленная, но подлинная («Маша. Я вам по совести» - (XIII, 33)).

Принципиально не игровое поведение героев в сфере семейных, материально-денежных отношений контрастирует с игровым мотивом, которым оформляется любовная коллизия, развивающаяся независимо от основного действия. Изящная любовная игра между Ниной и Тригориным (игра в чет и нечет, загадка медальона, любовное признание через книгу) обесценивает неэстетическую материальную реальность. Но когда откровенная, почти циничная игра Аркадиной с Тригориным превращается в средство жизни, ценности реального и театрального оказываются соизмеримыми. Мера игры и мера реальности как в жизни, так и в искусстве определяют необходимую гармонию. Этот принцип овеществляется в заключительной картине третьего акта, в которой восстанавливается прежняя оппозиция быта и бытия. Готовится отъезд Аркадиной, Тригорина, Нины в Москву, то есть выход героев из камерного частного мира в большой общий мир. Он предваряется «переодеванием», облачением в «форму» героев: «Горничная приносит Аркадиной шляпу, манто, зонтик, перчатки: все помогают Аркадиной одеться»; Сорин - «в пальто с пелериной, в шляпе, с палкой выходит из левой двери, проходя через комнату» (XIII, 34) - знаки перевоплощения приватного человека в публичного и «оформления» сырого жизненного материала. Затем натуральная - «бывалая», «шумная» - жизнь выплескивается за кулисы: «За сценой шум, какой бывает, когда провожают» (XIII, 44), а на сцене - первое и последнее решительное («жребий брошен») объяснение в любви Тригорина и Нины. Эта, пожалуй, лучшая любовная сцена в чеховском театре, в то же время наиболее полно демонстрирует его поэтику синтеза реального и условного, психологического и символического, текста и подтекста. Реальность глубокого психологического переживания передается в игровой театрализованной форме, которая находит выражение в театраль- 
но-патетической риторике речи персонажей (я решила бесповоротно, жребий брошен ... покидаю все, начинаю новую жизнь; Вы так прекрасны, о какое счастье, чудные глаза, невыразимо прекрасную ульюку, выражение ангельской чисmombl ... (XIII, 44)), в собственно игровых образах: поиск трости, жеребьевка. И главное - в игре подтекста, то есть в игре слов и образов, создающих фигуру иносказания. Кодом подтекста, как всегда у Чехова, является «ненужный» персонаж, вещь; в данном случае горничная и забытая корзинка со сливами задают тему ассоциативного ряда: горничная возвращается за забытой вещью (корзинкой); Тригорин возвращается за забытой вещью (тростью); Тригорин возвращается для встречи с Ниной (забытой вещью) ${ }^{1}$.

Семантическим эхом образа Нины - «забытой вещи» станет чучело чайки в четвертом действии:

«Шамраев (Тригорину). А у нас, Борис Алексеевич, осталась ваша вещь.

Тригорин. Какая?

Шамраев. Как-то Константин Гаврилович застрелил чайку, и вы поручили мне заказать из нее чучело.

Тригорин. Не помню» (XIII, 55).

В четвертом действии пространство «за сценой», как и в первом акте, приобретает глубину и наполненность. Первый его план составляют внутренние комнаты дома: слева - столовая, «через две комнаты» - гостиная с роялем, справа - повидимому, спальные комнаты. Второй план закулисного пространства занимают cad, театр Треплева, бушующее озеро. На дальнем плане - упоминаемый персонажами мир вне сцены: «за шесть верст» - дом Медведенко, где ждут мать, ребеночек, старуха, станция, куда уехала Аркадина встречать Тригорина, постояльий двор, где «уже дней пять» живет Нина, усадьба, куда ее «близко не подпускают отец и мачеха». Это внесценическое пространство - не драматическое, а эпическое романное; в него вливается внесценическая жизнь персонажей за два года, протекшие между третьим и четвертым действием. Главным во внесценическом действии является эпический мотив дороги, странничества, и главные его герои «бесприютные скитальцы», среди которых Нина и Медведенко. И совсем не случайно в их число попадают Аркадина и Тригорин. Тригорин, покидая дом Сорина, говорит об этом: «Значит, ехать? Опять вагоны, станции, буфеты, отбивные котлеты, разговоры ...» (третье действие, (XIII, 43)) и Нина повторит: «Завтра рано утром ехать в Елец в третьем классе ... с мужиками, а в Ельце образованные купцы будут приставать с любезностями» (XIII, 57). Мотив дороги и этот повтор создают образ «круговорота» жизни, в который попали Нина и Треплев. Круговорот жизни за сценой определяет оппозицию сценического хронотопа как драматического (не эпического) момента выхода из круговорота и, следовательно, момента кризиса и импульса возможного развития.

Творческий кризис Тригорина, Треплева, наиболее очевидный, выраженный тематически в репликах Тригорина, в монологе Треплева, не имеет характера глубокого поражения и не предполагает выхода из круговорота: оба писателя всего лишь собираются обменяться «приемами», чтобы поддержать свой публичный престиж. Самый этот кризис является симптомом и следствием глубинного распада личности, распада мира, которые выражаются сценическими средствами.

Выше, в связи с анализом декорации четвертого действия говорилось уже о том, что стена кабинета Треплева означает жесткое разъединение, расчуждение природного и человеческого, материального и духовного, социального и частного, и нарушение законов жизненного синтеза грозит общей дезорганизацией мира -

${ }^{1}$ В таком монтажном приеме построения смысла Чехов оказывается предтечей эйзенштейновской теории и практики метафорического кинообраза. (См. об этом [Хализев, 1978, c. 94]). 
«шевелением хаоса» и в природе (ужасная погода, на озере волны. Громадные (XIII, 45)), и в культуре (театр стоит гольій, безобразный), и в духе (хаос грез и образов (XIII, 59)).

Движение персонажей между сценой и засценическим пространством отражает окончательный разрыв коммуникаций между Треплевым и другими, наметившийся в первом действии. Внешне, в зоне сцены-игры достигнуто примирение, взаимное прощение и сочувственное общение, но дислокация персонажей показывает другое: когда все на сцене, Треплев уходит, а когда все уходят, Треплев - на сцене. Но и тогда, когда Треплев и другие в одном сценическом пространстве, они существуют параллельно: все играют за ломберным столом, а Треплев «тихо входит и идет к своему» - письменному - столу. Мало того, всякие попытки общения немедленно пресекаются либо со стороны Треплева, отвечающего отказом на приглашение матери принять участие в игре, в ужине, либо со стороны Аркадиной («Охота обращать внимание»). Особенно откровенен ответ Аркадиной на вопрос Дорна «Ирина Николаевна, вы рады, что у вас сын писатель?» - «Представьте, я еще не читала. Все некогда» (XIII, 54). Выразив пренебрежение к делу сына, она еще и ушла от ответа на вопрос «рада ли?» и тем выдала свою мелкую ревность и зависть, не щадящую даже родного человека.

Внутренний душевный разлад выражается, как и во втором действии, отношением между сценическим и засценическим пространством как игровым и неигровым. Игровой характер сцены так же обозначен прямым образом - игра в лото. Поведение героев на сцене ролевое, но доведенное до отрыва роли от лица, формы от сущности, маски от души. Аркадина, черствая к сыну и всему окружающему, оживает лишь в роли актрисы, в рассказах о том, как ее «в Харькове принимали». Харьков - не Москва, не Петербург, налицо кризис успеха и тем активнее она играет в успех - «голова кружится». Игра-мистификация Треплева также окончательно оформилась в публичную твердую роль: «...никто не знает вашей настоящей фамилии, так как вы печатаетесь под псевдонимом. Вы таинственны как Железная маска» (XIII, 52). Кроме того, он явно перенял у Тригорина роль модного беллетриста. На сцене он всегда («дни и ночи») у письменного стола, с книжкой или рукописями («Костя, оставь свои рукописи, пойдем есть. - Не хочу, мама, я сыт» (XIII, 55)). Маска его на сцене, а душа - за сценой. На сцене - «сытый» писатель - за сценой «бедная», «тоскующая», «беспокойная» душа, выражающая себя то в звуках меланхолического вальса, то в порывах за пределы сцены, за окно («распахивает окно, прислушивается»). Творческий кризис Треплева - следствие разъединения живой души и роли писателя. Сознание того, что «дело не в старых и не в новых формах, а в том, что человек пишет, не думая ни о каких формах, пишет, потому что это свободно льется из его души» (XIII, 56), пришло тогда, когда душа человека отделилась от письма и, чтобы он ни писал, «все это сухо, черство, мрачно» (XIII, 57). А обескровленное письмо рождает в Треплеве тот же тригоринский вампиризм. Как Тригорин «забыл, как чувствуют себя в 18 - 19 лет», так и у Треплева «молодость ... вдруг как оторвало» (XIII, 57). И как Тригорин тянется к животворному теплу Нины, так и Треплев молит ее о том же: «Я одинок, не согрет ни чьей привязанностью, мне холодно, как в подземелье ... останьтесь здесь, Нина ...» (XIII, 57). Театрально-игровое действие Треплева здесь разоблачается, как и в тригоринском монологе второго акта, читкой, самоцитацией из его «декадентской» пьесы: «Я одинока ... холодно, холодно, холодно ... как пленник, брошенный в пустой глубокий колодец ...» (XIII, 13-14).

До логического конца доводится функция Тригорина - ловца душ, явившегося за еще живой и тоскующей душой Треплева. Этот иронико-мистический смысл роли Тригорина раскрывается рядом деталей игры в лото. Ее особый знаковый характер выражается прежде всего в большом объеме текста, занятого ею. В мотиве спешки, с которой приступают к игре: сразу же после приезда и первых слов 
приветствия Тригорина и после его фразы с тем же мотивом «Тороплюсь кончить повесть» и особенно: «Одним словом - старая история», намекающая на ту же, старую историю торопливого «улова» в новую повесть судьбы Нины (сравн. «Тригорин ... (смотрит на часы) Я должен сейчас идти и писать. Извините, мне некогда ...» (второй акт, (XIII, 29). Реплика Полины Андреевны усиливает особый смысл этого мотива: «(стучит по столу). Пожалуйте, господа. Не будем терять времени, а то скоро ужинать позовут» (XIII, 53). Игра азартная - на денежную ставку. Но истинной ставкой является не мелкая монета, а жизнь Треплева. Цену ставки определяет Аркадина - «гривенник», что соответствует цене, какую она дает сыну («я еще не читала. Все некогда»). Треплев - вне игры, но именно его судят в течение всей игры, и это еще один косвенный знак ее настоящей ставки. Связь игры с реальными лицами раскрывается в остроумном обыгрывании приемов лото, а именно - выкликания чисел, которые в речевом контексте, сопровождающем игру приобретают новые ситуативные смыслы. Аркадина. Рассказывая о подарках харьковской публики, «снимает с груди брошь и бросает на стол».

«Шамраев. Да, это вещь ...

Маша. Пятьдесят! ...

Дорн. Ровно пятьдесят?» (XIII, 53).

Или: Маша кричит «Одиннадцать!», это число в игровом жаргоне имеет еще название «барабанные палочки», не случайно в этот момент Аркадина «оглядывается на Сорина» Дорн объявляет: «Спит действительный статский советник», - и Маша кричит: «Семь! Девяносто!», что в лото означает «Кочерга» и «Дед» ${ }^{1}$. Комический тон развивает мотив рыбной ловли, иносказательный смысл которого здесь разоблачается нелогическим стыком реплик о рыбе и о Треплеве:

«Тригорин. Поймать ерша или окуня - это такое блаженство!

Дорн. А я верю в Константина Гавриловича. Что-то есть!» (XIII, 54).

То есть Тригорин уже видит Треплева на крючке, а Дорн еще защищает его право на жизнь.

Трагикомический же пафос игры в лото обусловлен тем, что она идет в последний час жизни Треплева. И счет минутам не случайно ведет Маша: в судьбе Треплева и ее жребий: в начале третьего акта она говорит об этом: «Я вам по совести, если бы он ранил себя серьезно, то я не стала бы жить ни одной минуты» (XIII, 33). К концу партии числа, выкликаемые ею, приобретают все более мистический характер и прямо связываются с поведением Треплева: на числе «26»«очко» - он «тихо входит», в момент объявления числа «66» («туда - сюда» - термин игры в лото - С.К.) «распахивает окно, прислушивается», испытывая «беспокойство». Числом «88» партия заканчивается. Выигрывает Тригорин: быть жизни и смерти Треплева в его «улове» - в записной книжке, откуда, по заказу, претворится в очередное чучело, которое будет храниться в книжном шкафу, как и чучело чайки.

Нина, появившись из-за сцены в игровом сценическом пространстве так же, как и другие герои, занята своим самоопределением в искусстве. Но в то время, как другие души, из которых должно «свободно литься» искусство, черствеют под отвердевшими ролевыми масками, душа Нины, напротив, освобождается от ролей, которые ей были предназначены. Трижды отрекается она от роли и образа чайки в той же самой последовательности, какой они были ей даны. В первый раз в самом начале пьесы она сама называет, избирает роль чайки с ее тягой к озеру, к богеме,

${ }^{1}$ В рассказе Чехова «Детвора» игра в лото названна «азартной» и там же говорится о «терминах и смехотворных прозвищах» в игре: «Так, семь у игроков называется кочергой, одиннадцать - палочками, семьдесят семь - Семен Семеныч, девяносто - дедушкой и т.д.» (IV, 316). 
в актрисы, к славе (XIII, 10). В финале, снова притянутая к озеру, к богеме, она воскрешает эту свою роль, но тургеневский контекст, в котором она вспоминает ее, заставляет от нее отречься: «Я - чайка ... Нет, не то. (Трет себе лоб). О чем я? Да ... Тургенев ...» (XIII, 57). Дело в том, что место из тургеневского «Рудина», цитируемое Ниной, содержит сцену, аналогичную чеховскому эпизоду: Лежнев предлагает «бесприютному скитальцу» Рудину свой дом, «теплый уголок», «гнездо», куда он мог бы укрыться. Рудин заявляет, что он «не стоит приюта», на что Лежнев говорит: «Каждый остается тем, чем сделала его природа, и больше требовать от него нельзя» [Тургенев, 1968, с. 562]. Верность своей природе - первый опыт настоящей актрисы. Затем, после признаний и мольбы Треплева Нина играет образ чайки, сотворенный им, - убитой чайки: «Зачем вы говорите, что целовали землю, по которой я ходила? Меня надо убить» (XIII, 58) - и смерть ей желанна как свобода от вины, от утомления. Но и этой роли она позволить себе не может, так как ощущает себя уже не только грешным, уставшим человеком, но и сознает свое призвание и необходимость следовать ему: «Я - чайка ... Не то. Я - актриса. Ну, да!» (XIII, 58). Наконец, услышав «смех Тригорина», она вспоминает третью роль чайки, предназначенную Нине в его «сюжете для небольшого рассказа», роль погубленной от нечего делать случайным человеком души (XIII, 58). И от этой роли она отрекается особенно решительно, как и от манеры игры, обусловленной этой ролью: «... перестала верить и пала духом ... играла ужасно. Я - чайка. Нет , не то ... Теперь уж я не так ... Я уже настоящая актриса, я играю с наслаждением ...» (XIII, 58). Повторяющиеся жесты, сопровождающие слова отречения - трет себе лоб, поднимает голову, - означают и срывание с лица «фальшивых» масок, и трудное рождение мысли, и высвобождение, подъем «упавшего духа»: «Все хожу и думаю, думаю и чувствую, как с каждым днем растут мои душевные силы» (XIII, 58). Однако, освобождаясь из-под власти навязанных чужих ролей, Нина ничего не забыла, в отличие от Тригорина или Треплева, ничего «не оторвало» от ее души: ни чистой молодости, ни грешной любви. Мало того, именно теперь она поняла и приняла ту роль «мировой души», в которой когда-то видела не живые лица, а только «читку». Теперь она, сумела вдохнуть живое тепло в «отвлеченную» идею, играет с наслаждением ту «мировую душу», которая «помнит все, все, все и каждую жизнь в себе самой переживает вновь» (XIII, 13). Нина осуществляет таким образом новый синтез в искусстве.

Нина и Треплев покидают сцену в разных направлениях: Нина «убегает в стеклянную дверь», за которой «театр», сад, озеро; Треплев - в «правую дверь», во внутренние покои. И, следовательно, не встретятся за сценой. Но оба они за сценой убегут из круговорота жизненной суеты и спешки, в котором суждено вращаться всем другим персонажам пьесы. Нина и Треплев прорывают кольцо, раму, декорацию, уходят за пределы сцены и текста пьесы, хотя и с разными мотивами: Треплев отрицает этот театр, не желая более быть зрителем спектакля, где «люди едят, пьют, любят, ходят, носят свои пиджаки». Нина утверждает его своим желанием «стать большой актрисой», так как знает иной и высший смысл театра жизни.

Итак, сцена как образ искусства и образ жизни противостоит у Чехова несцене как игра - серьезности. Игровой характер мира на сцене коррелируется засценическими, то есть неигровыми элементами жизни: трудовая, социальная, частная деятельность человека. Они же регулируют аксиологический аспект сцены, оценку различных форм и правил игры; главными критериями ценности сценического мира являются мера и синтез.

\section{Литература}

Балухатый С.Д. Драматургия Чехова. // Проблемы драматургического анали- 
за. Л., 1927.

Григорьев М.С. Приемы сценического воздействия на зрителя в пьесах Чехова или сценическая композиция чеховских пьес. М., 1924.

Козлова С.М. Литературный диалог в комедии А.П. Чехова «Чайка» // Известия АГУ. 2001. № 4.

Тургенев И.С. Рудин // И.С. Тургенев. Собрание сочинений: В 6-ти т. Т. 1. М. 1968.

Фарыно Е. Семиотика чеховской «Чайки» // Русский текст. Российскоамериканский журнал по русской филологии. 1994. № 2.

Хализев В. Драма как явление искусства. М., 1978.

Чехов А.П. Полное собрание сочинений: В 30-ти т. Т. 13. М., 1978.

Шалюгин Г.А. Сон Константина Треплева (неизвестные источники пьесы «Чайка») // Чеховские чтения в Ялте: Чехов в меняющемся мире. М. 1993. 